\title{
A NEW TERRESTRIAL ISOPOD FROM GUATEMALA, THE TYPE OF A NEW GENUS.
}

\section{By Harriet Richardson,} Collaborator, Division of Marine Invertebrates, U. S. National Museum.

The following description is of a new isopod which was collected by Messrs. E. A. Schwarz and H. S. Barber, in the spring of 1906, at Livingston, Guatemala, and is now deposited in the United States National Museum. The single specimen found is the type of a new genus.

$$
\text { Family ARMADILLIDIDA. }
$$

\section{SPHERARMADILLO, new genus.}

Description.-Head margined in front. Frontal margin straight. Epistome with a slight shield-like convexity. Flagellum of second pair of antennæ composed of three articles. Eyes absent.

First thoracic segment with the epimera or coxopodites on the underside, extending almost the entire length of the lateral margin in the form of a wide band, not reaching the posterior margin of the segment and being cleft posteriorly by a rather deep fissure. The position and form of the coxopodite gives the lateral margin of the segment a thickened appearance. The epimera or coxopodites are not present on any of the following segments.

The terminal abdominal segment is triangular, with the apex obtusely rounded. The basal article of the uropoda is quadrangular, broader than long, not reaching beyond the lateral parts of the fifth abdominal segment, but extending considerably beyond the apex of the terminal abdominal segment. The inner branch extends considerably beyond the apex of the sixth abdominal segment and reaches a little beyond the inner post-lateral angle of the basal article of the uropoda. The outer branch is inserted in a notch about the middle of the inner lateral margin of the basal article and occupies a lateral position.

Type of genus.-Spherarmadillo schwarzi.

Proc. N. M. vol. xxxii-07-29 
SPHERARMADILLO SCHWARZI, new species.

Description.-Body convex, contractile into a ball, a little more than twice as long as wide, $50 \mathrm{~mm}$. by $22 \mathrm{~mm}$. Color yellow, with numerous arborescent markings of dark brown.

Head much wider than long, $3 \mathrm{~mm}$. by $10 \mathrm{~mm}$. with the front straight and margined. The epistome has a slight shield-like convexity. There is no trace of eyes. The first pair of antennæ are rudimentary and inconspicuous. The second pair have the first article small; the second is about twice as long as the first; the third is equal

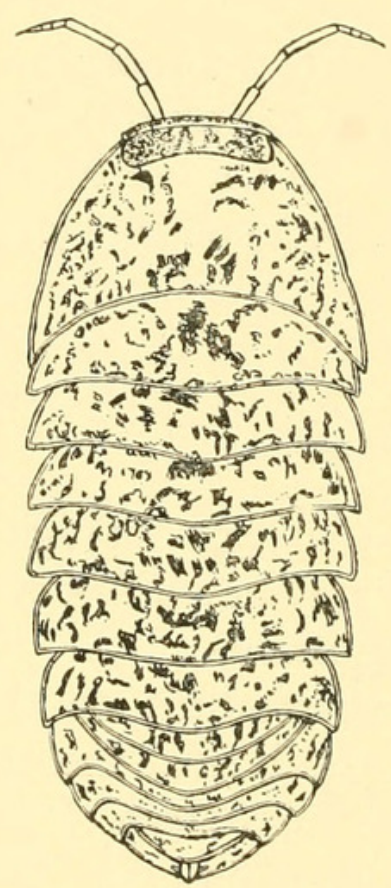

$a$
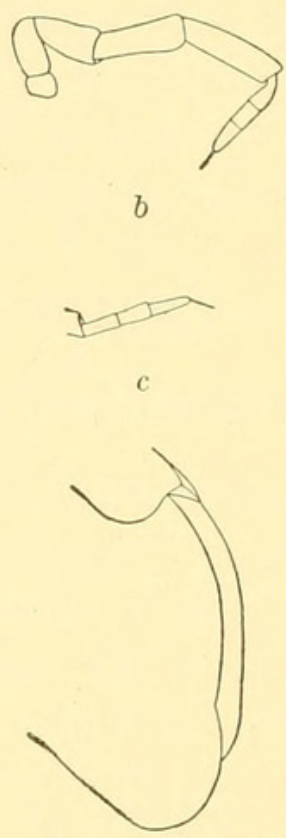

$d$
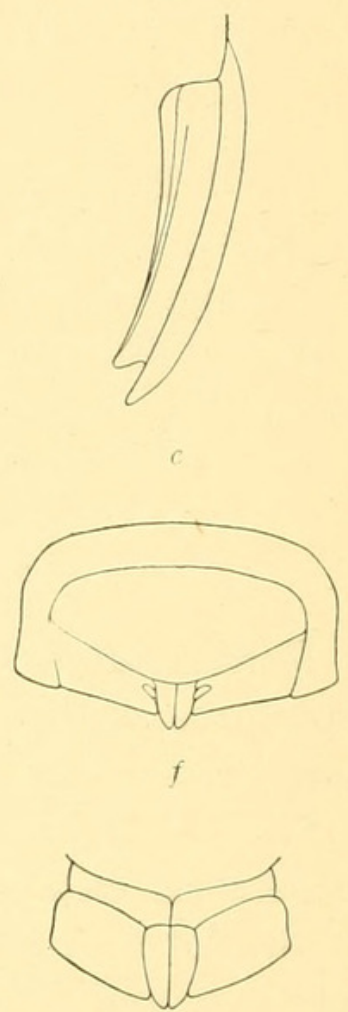

$g$

Spherarmadillo schwarzi, $a$, Dorsal view, $\mathrm{x} 3 ; b$, Second antenna, $\mathrm{x} 7 ; c$, Flagellum of SECOND ANTENNA, $\mathrm{x} 7 ; d$, LATERAL PART OF FIRST THORACIC SEGMENT (LATERAL VIEW), $\mathrm{x} \quad 7$; $e$, LATERAL PART OF FIRST THORACIC SEgMENT (VENTRAL VIEW), $\mathrm{x} 7 ; f$, LAST TWO SEgMENTS OF ABDOMEN WITH UROPODA, x $7 ; g$, UROPODA (VENTRAL VIEW), $\mathrm{x} 7$.

in length to the second; the fourth is one and a half times as long as the third; the fifth is a little longer than the fourth. The flagellum is composed of three articles, the middle one of which is slightly shorter than either of the others, which are subequal.

The first thoracic segment is nearly twice as long as any of the following segments which are subequal. The first segment is $9 \mathrm{~mm}$. in length. Each of the following is about $5 \mathrm{~mm}$. long. The lateral parts of the first segment are slightly produced backward in rounded lobes. Epimera or coxopodites are present on the underside and extend in the form of a wide band along the entire lateral margin almost to the posterior margin and are cleft posteriorly by a rather deep fissure. The form and position of the coxopodites give a ihick- 
ened appearance to the lateral margin. Epimera are not present on any of the following thoracic segments.

The first segment of the abdomen is the longest, being $3 \mathrm{~mm}$. in length. The two following segments are subequal and each is $2 \mathrm{~mm}$. long. The next two segments, the fourth and fifth, are subequal and each is $1.5 \mathrm{~mm}$. in length. The first two segments are covered laterally by the seventh thoracic segment. The sixth or terminal segment is triangular in shape. It is $9 \mathrm{~mm}$. wide at the base and $4 \mathrm{~mm}$. long in the median longitudinal line. The apex is obtusely rounded. The basal article of the uropoda occupies all the space between the terminal segment of the abdomen and the produced lateral parts of the fifth segment. It does not extend beyond the lateral parts of the fifth segment, but extends considerably beyond the apex of the triangular terminal segment. In shape it is quadrangular, broader than long, with the inner anterior part covered by the apical portion of the terminal abdominal segment. The inner branch of the uropoda extends considerably beyond the apex of the terminal abdominal segment and a little beyond the inner post-lateral angle of the basal article. The outer branch is inserted in a deep notch about the middle of the inner lateral margin of the basal article. This branch lies in a lateral position.

All the legs are ambulatory.

The type and only specimen was collected at Livingston, Guatemala, by Messrs. E. A. Schwarz and H. S. Barber, in April, 1906, and is in the U. S. National Museum. Cat. No. 33471.

This genus is perhaps more closely related to Sphæroniscus Gerstæcker than to any other genus of the Armadillididæ, these two being the only genera of that family in which the flagellum of the second antennæ is composed of three articles. Spherarmadillo schwarzi more closely resembles Sphæroniscus portoricensis Richardson ${ }^{a}$ than the other species of that genus in the shape of the terminal abdominal segment, the basal article of the uropoda, and the form and position of the inner branch. It differs, however, from that species in the absence of eyes, the presence of distinct coxopodites on the underside of the first thoracic segment, and in the form and position of the outer branch of the uropoda. This branch is inserted in a notch in the middle of the inner lateral margin of the basal article, and it is this character which distinguishes it from all the species belonging to the genus Sphæroniscus.

This genus also resembles Synarmadillo Dollfus ${ }^{b}$ in the form of the

$a$ Proc. U. S. National Museum, XXIII, 1901, p. 573; Bull. U. S. National Museum, No. 54, 1905, pp. 662-663.

$b$ Ann. Soc. Entomologique de France, LXI, 1892, pp. 388-389, pl. viI, fig. 4. 
terminal segment of the abdomen, the shape of the basal article of the uropoda, and the form and position of the inner branch. It differs, however, from that genus in having three articles instead of two to the flagellum of the second antennæ, in the form and position of the outer branch of the uropoda, which is inserted in a notch about the middle of the inner lateral margin of the basal article instead of at the inner post-lateral angle of that article as in Synarmadillo. The terminal abdominal segment is also shorter than in Synarmadillo, exposing more of the inner branches of the uropoda.

This species is named after Mr. E. A. Schwarz, custodian of Coleoptera in the U. S. National Museum, who collected the specimen. 


\section{$2 \mathrm{BHL}$ Biodiversity Heritage Library}

Richardson, Harriet. 1907. "A new terrestrial isopod from Guatemala, the type of a new genus." Proceedings of the United States National Museum 32(1535), 447-450. https://doi.org/10.5479/si.00963801.32-1535.447.

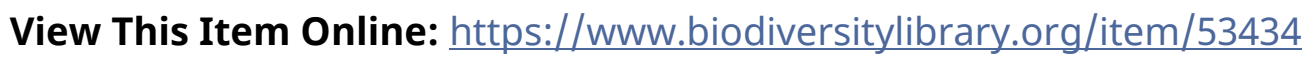

DOI: https://doi.org/10.5479/si.00963801.32-1535.447

Permalink: https://www.biodiversitylibrary.org/partpdf/51882

\section{Holding Institution}

Smithsonian Libraries

\section{Sponsored by}

Smithsonian

\section{Copyright \& Reuse}

Copyright Status: Public domain. The BHL considers that this work is no longer under copyright protection.

This document was created from content at the Biodiversity Heritage Library, the world's largest open access digital library for biodiversity literature and archives. Visit BHL at https://www.biodiversitylibrary.org. 